\title{
Histopathology of the interaction between Ascochyta fabae and Vicia faba: comparison of susceptible and resistant reactions
}

\author{
N Maurin ${ }^{1^{*}}$, JP Gourret 2, B Tivoli 1 \\ 1 INRA, CR de Rennes, Station de Pathologie Végétale, BP 29, F35650 Le Rheu; \\ 2 Laboratoire de Biologie Cellulaire, Université de Rennes I, av du Général-Leclerc, F35042 Rennes Cedex, France
}

(Received 26 May 1993; accepted 10 September 1993)

\begin{abstract}
Summary - Leaves of Vicia faba plants naturally or artificially infected with Ascochyta fabae were examined using light, scanning and transmission electron microscopy. Histological comparison was made of 1 resistant $(29 \mathrm{H})$ line and 1 susceptible (48B) line to study possible differences in symptom expression, host-cell necrosis and extent of fungal development. In the susceptible line, 48B, a lesion consisted of a central necrotic region where the fungus invaded intercellular spaces between the epidermis and the mesophyll. Although no fungal hyphae were found in the surrounding region, many cells had collapsed. In the resistant line, $29 \mathrm{H}$, the fungus failed to develop during penetration. The host cells underlying fungal spores became orange-brown and a hypersensitive reaction caused flecking lesions. In addition, the granal lamellae of chloroplasts of the adjacent mesophyll cells were swollen and electron translucent. Necrotic lesions appeared in a few cases but remained limited. At the periphery of this lesion, many electron-dense bodies were attached to the walls of mesophyll cells.
\end{abstract}

\section{Ascochyta fabae / Vicia faba / interaction / resistance / ultrastructure}

Résumé - Histopathologie de l'interaction entre Ascochyta fabae et Vicia faba. Comparaison des réactions de sensibilité et de résistance. Des feuilles de féverole Nicia faba $L$ ) prélevées sur des plantes naturellement et artifiellement infectées par Ascochyta fabae sont examinées en microscopie photonique et électronique à balayage et à transmission. Une lignée résistante $(29 \mathrm{H})$ est comparée d'un point de vue histologique à une lignée sensible (48B) afin de mettre en évidence d'éventuelles différences dans la symptomalogie, dans la colonisation des tissus par le parasite et dans les altérations produites sur les cellules hôtes. Chez la lignée sensible 48B, les lésions présentent une zone centrale nécrosée où le champignon envahit les espaces intercellulaires compris entre l'épiderme et le mésophylle. À la périphérie, beaucoup de cellules sont mortes sans colonisation des tissus par les hyphes du champignon. Chez la lignée résistante, le développement du parasite semble interrompu lors de la pénétration. Les cellules épidermiques en contact avec les spores du champignon brunissent et sont à l'origine d'une réaction hypersensible se traduisant par des «points rouille». De plus, les lamelles des thylakoïdes des chloroplastes situés dans les cellules adjacentes sont épaissies et transparentes aux électrons. Dans quelques cas, de véritables nécroses apparaissent, mais celles-ci restent limitées. $\dot{A}$ la périphérie de ce type de symptôme, les parois des cellules du mésophylle présentent de nombreux corpuscules denses aux électrons.

Ascochyta fabae / Vicia faba / interaction / résistance / ultrastructure

\section{INTRODUCTION}

Ascochyta fabae Speg is the causal agent of leaf, stem and pod spot disease of faba beans, Vicia faba L. Various methods of assessing disease reaction have been proposed (Jellis et al, 1984; Lockwood et al, 1985; van Breukelen,
1985; Tivoli et al, 1987; Pritchard et al, 1989). Differences in resistance to artificial inoculation among faba bean genotypes were demonstrated in field trials (Jellis et al, 1985; Maurin, 1989). In susceptible interactions the fungus spreads throughout the canopy whereas in resistant interactions it is confined to the lower leaves

\footnotetext{
* Correspondence and reprints
} 
(Maurin and Tivoli, 1992). However, little attention has been paid to qualitative differences in lesion type.

The principal objective of this work was to describe the differences in the extent of fungal development, host-cell necrosis and symptom expression during the reaction of a resistant $(29 \mathrm{H})$ line and a susceptible (48B) line of $V$ faba to $A$ fabae.

\section{MATERIALS AND METHODS}

The $V$ faba lines $29 \mathrm{H}$ and $48 \mathrm{~B}$ were naturally and artificially infected with $A$ fabae under field and greenhouse conditions.

\section{Plants}

Seeds stocks were obtained from $\mathrm{Dr}$ Berthelem (INRA, Station d'Amélioration des Plantes, Le Rheu, France). Plants for experimental purposes were grown individually in $9-\mathrm{cm}$ pots under glasshouse conditions up to the 6-8 leaf stage (artificial inoculation) or collected from field trials (naturally infected).

\section{Cultures and inoculum}

Cultures of $A$ fabae were isolated from infected leaves or infected pods. Artificial inoculations were carried out using single spore isolates. Spore suspensions were prepared by flooding the surface of V8 juice agar cultures (14-d old) with sterile distilled water and scraping with a glass rake. Mycelium debris was removed by filtration through 2 layers of sterile gauze. The concentration was adjusted to $5 \times 10^{5}$ spores $/ \mathrm{ml}$ with the aid of a haemacytometer.

\section{Method of inoculation}

Each plant was sprayed with $5 \mathrm{ml}$ of the spore suspension and then enclosed in a plastic bag for $48 \mathrm{~h}$. The inoculated plants were maintained at $15^{\circ} \mathrm{C}$ for 2 weeks and moistened with sterile water twice daily.

\section{Microscopic examination}

$\checkmark$ faba leaves were fixed in $2.5 \%$ glutaraldehyde dissolved in $0.5 \mathrm{M}$ sodium cacodylate buffer at $\mathrm{pH} 7.2$ and stored overnight at $5^{\circ} \mathrm{C}$. They were washed twice in buffer and fixed in $2 \%$ osmium tetroxide. After a further 2 washes in buffer, dehydration was achieved using a graded ethanol series.

For scanning electron microscopy (SEM), samples were critical-point dried in carbon dioxide after a graded transition from ethanol to acetone. Sections $(5 \times 5$ $\mathrm{mm}$ ) were mounted on stubs, coated with gold and examined with a Hitachi S-570 SEM operating at 5 or 8 $k V$.

For transmission electron microscopy (TEM) samples were graded transitionally from ethanol to propylene oxide, impregnated with resin (Epon) and stored overnight at laboratory temperature. The samples were then embedded in Epon with catalyst (DMP 30) and kept for $2 \mathrm{~d}$ at $50^{\circ} \mathrm{C}$ for polymerization of the resin. An LKB ultramicrotome was used to cut 50$90 \mathrm{~nm}$ sections for TEM examination. The TEM sections were stained with $5 \%$ aqueous uranyl acetate and lead citrate (Reynolds, 1963) and examined using a Jeol JEM $100 \mathrm{CX}$ electron microscope operating at $80 \mathrm{kV}$. The presence of polysaccharides was assessed using the PATAg reaction method (Thiery, 1967).

\section{RESULTS}

\section{Lesion development on leaves}

When the $2 V$ faba lines were grown in the field in soil infested with $A$ fabae a greater number of lesions developed on the susceptible line 48B than on the resistant line $29 \mathrm{H}$. Furthermore, there was a qualitative difference in lesion types on the 2 lines.

On the susceptible line $48 \mathrm{~B}$, lesions were 5$35 \mathrm{~mm}$ in diameter with a grey centre containing prominent pycnidia (fig 1a). The host tissue in the centre was thin, fragile and often collapsed to leave a hole. Surrounding this area was a blackbrown region consisting of concentric dark and light bands which contained no pycnidia. The size of this well-defined outer area appeared to be related to lesion age and climatic conditions. In about $25 \%$ of the lesions, the necrotic area, surrounding the central region containing pycnidia, spread widely and formed more irregular and less clearly defined borders (fig 1b). In artificial inoculation conditions at $15^{\circ} \mathrm{C}$, necrosis appeared after $8 \mathrm{~d}$ incubation and lesions became identical to those observed in the field.

Fig 1. Leaves of $V$ faba infected with Ascochyta fabae. On the susceptible line 48B, lesions contain pycnidia (a) and spread widely (b); on the resistant line $29 \mathrm{H}$, symptoms consist of limited lesions (c) and flecking lesions (d, e and f). Arrows: origin of the spreading lesions. Bars represent $2.5 \mathrm{~mm}$ for $\mathrm{a}-\mathrm{d}$ and $50 \mu \mathrm{m}$ for $\mathrm{e}-\mathrm{f}$. 
b

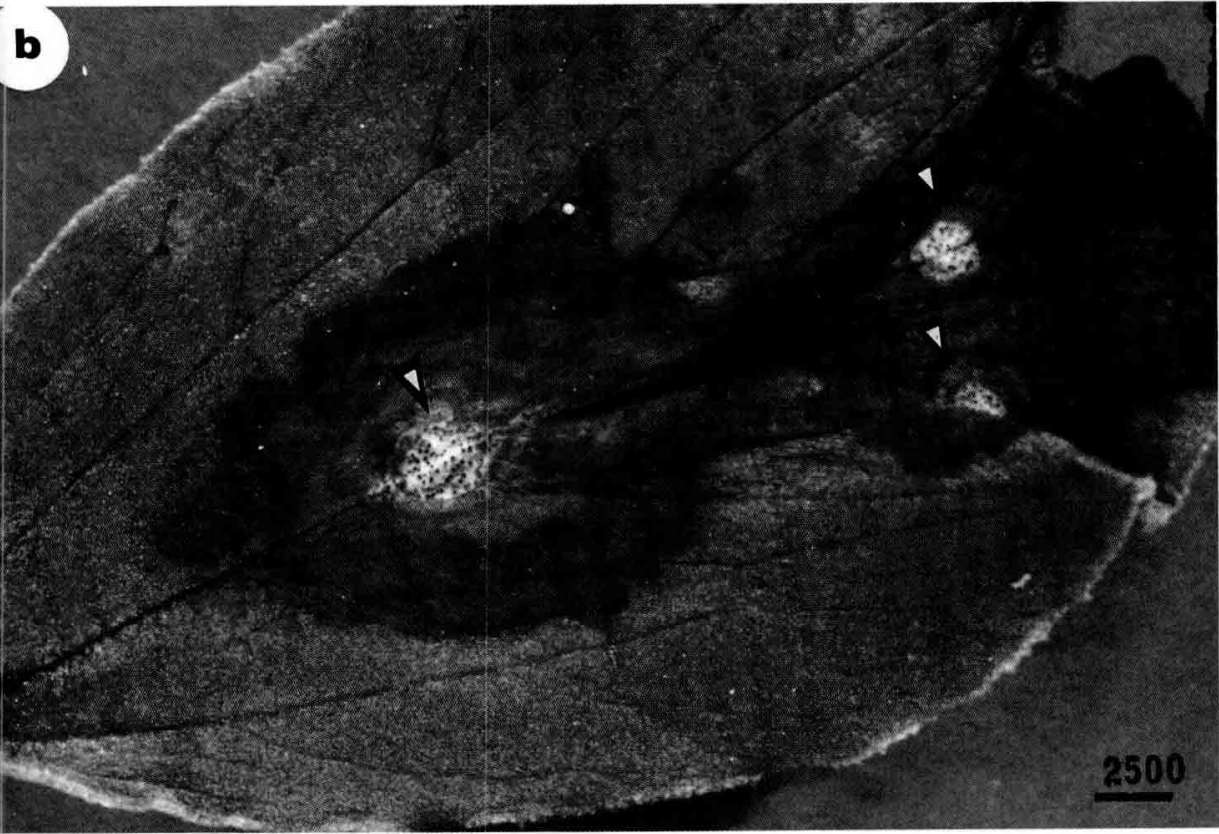

c

(2)
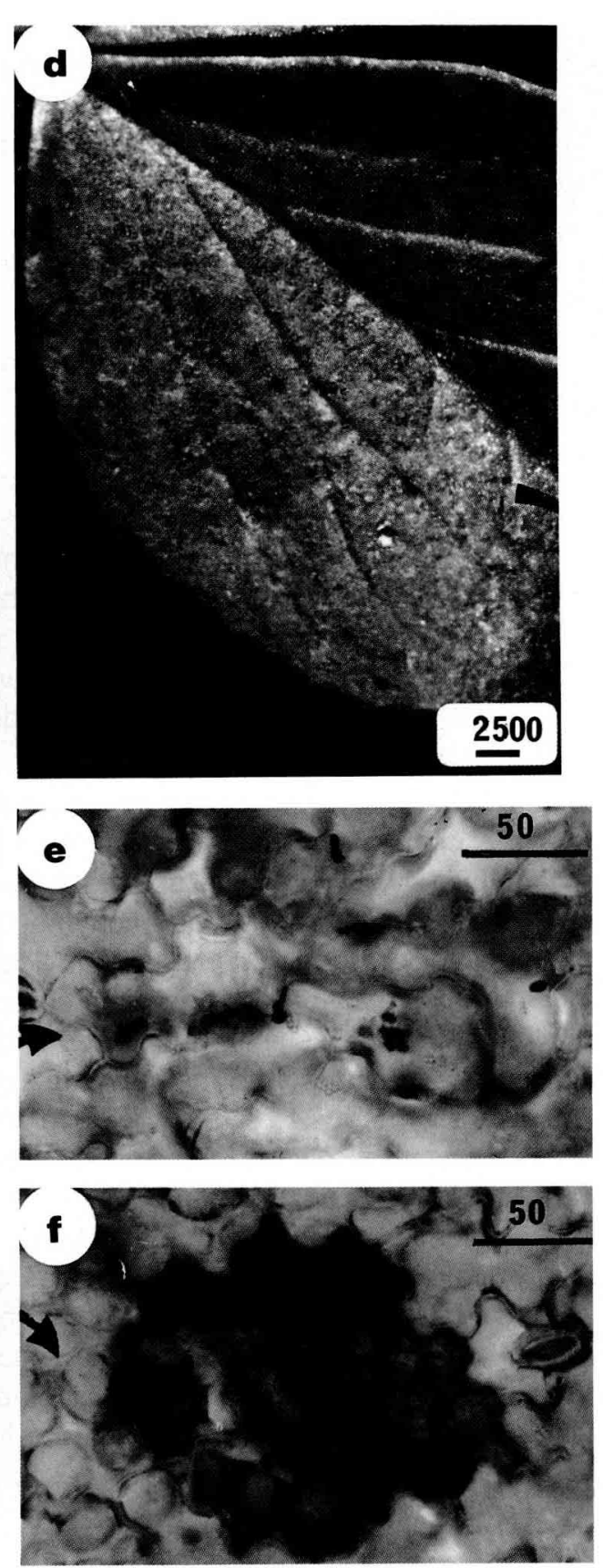
On the resistant line $29 \mathrm{H}, 95 \%$ of all lesions found were individual brown dots that did not exceed $0.5 \mathrm{~mm}$ and which were irregularly distributed mainly on the upper surface of leaves (figs $1 d-f)$. These are described as flecking lesions. The other symptom was a limited lesion enclosed by a highly defined border which was a red-brown colour (fig 1c). In artificial inoculation conditions at $15^{\circ} \mathrm{C}$, flecking lesions appeared within $1 \mathrm{~d}$ of incubation and remained restricted to a few cells. The limited lesions appeared as in the susceptible line but they did not spread.

\section{Microscopic examination of infection}

A fabae spores coated in mucilage adhered to leaf surfaces of $V$ faba plants. Within $24 \mathrm{~h}$ in the presence of free water, the spores developed more or less branching germ tubes which grew on the leaf surface. Germ tube tips swelled and developed perpendicularly to form an appresorium. Infection pegs grew from the appressoria, penetrated the host cuticle and developed between epidermal cells. Hyphae invaded the intercellular spaces between palisade parenchyma cells.

In the centre of lesions occurring on the susceptible line, hyphae were found to invade completely all available spaces between epidermal cells. Although the parenchyma tissue remained intact, the epidermis and cuticle were almost completely destroyed. In the outer region cell destruction was less widespread and the parenchyma structure was maintained. Although the mycelium of $A$ fabae became less and less apparent towards the periphery of this outer region, the destruction of the host cells was evident in advance of fungal hyphae. Hyphae, when found, were often in the spaces around vessels of the vascular bundle and some even developed within xylem elements which became obstructed with gum. In the black-brown-coloured spreading region of lesions, the fungus was not detected but the mesophyll cells had collapsed.
In contrast, on the resistant line, microscopic examination of the lesions showed that there was no host cell destruction or pycnidia production in flecking lesions. In such lesions a small group of intact host cells were found to be orange-brown coloured (fig 1f) and seemed to contain tannin. SEM revealed that most of these flecking lesions consisted of a slightly depressed area on the leaf surface (fig 2a). The mesophyll cells underlying such lesions showed ultrastructural modifications, ie the inner space of thylakoids was electron dense and slightly swollen (figs $2 b, c)$. There was also an increase in the number and size of plastoglobi.

The only difference between limited lesions in the resistant line and lesions in the susceptible line was the occurrence of numerous electrondense bodies attached to the external walls of mesophyll cells at the border of lesions (fig 2d). These bodies showed no reaction in PATAg polysaccharide test (fig 2e).

The resistant line $29 \mathrm{H}$ produced either a hypersensitive reaction to infection, ie flecking lesions, or a highly restricted lesion, ie limited lesions. Conversely the susceptible line 48B produced a lesion which was sometimes large and spreading. The centre of the necrosis was associated with intercellular pathogen growth, host-cell death and the production of pycnidia.

\section{DISCUSSION}

On leaves of $V$ faba, the type of lesions produced by $A$ fabae in resistant reactions were diferent to those found in susceptible responses. Similar findings have been found with other plant species by Ou (1980), Darby et al (1986) and O'Connell and Bailey (1988). The type of lesion produced reflected the ability of the faba bean to restrict fungal development, ie ranging from complete arrest of the pathogen, as represented by flecking lesions, through limited to spreading lesions. In spreading lesions $A$ fabae appears to colonise host tissue without restraint.

Fig 2. Microscopic examination of symptoms caused by $A$ fabae infection on the resistant line $29 \mathrm{H}$ : (a) a flecking lesion consists of a slightly flattened area (arrow) on the leaf surface (SEM). Es: epidermis. Bar represents $100 \mu \mathrm{m}$; (b) and (c) ultrastructure of chloroplast grana of a mesophyll cell underlying flecking lesions. The inner space of the thylakoids of the cells close to a flecking lesion is swollen (b) and filled with an electron-dense substance (arrow), but is electron-transparent (arrow) in healthy tissue (c). TEM Bar represents $0.1 \mu \mathrm{m}$; (d) boundary of a limited lesion on the resistant line $29 \mathrm{H}$ showing the presense of electron-dense bodies (arrows) attached to the external walls of mesophyll cells (SEM). Pa: palisade parenchyma. Bar represents $40 \mu$ m; (e) PATAg polysaccharide test of leaf lamina at the boundary of a limited lesion on the resistant line $29 \mathrm{H}$. Starch grains and pectocellulosic wall compounds react strongly, unlike the electron-dense bodies (TEM). W: wall, st: starch, and DB: electron-dense bodies. Bar represents $1 \mu \mathrm{m}$. 

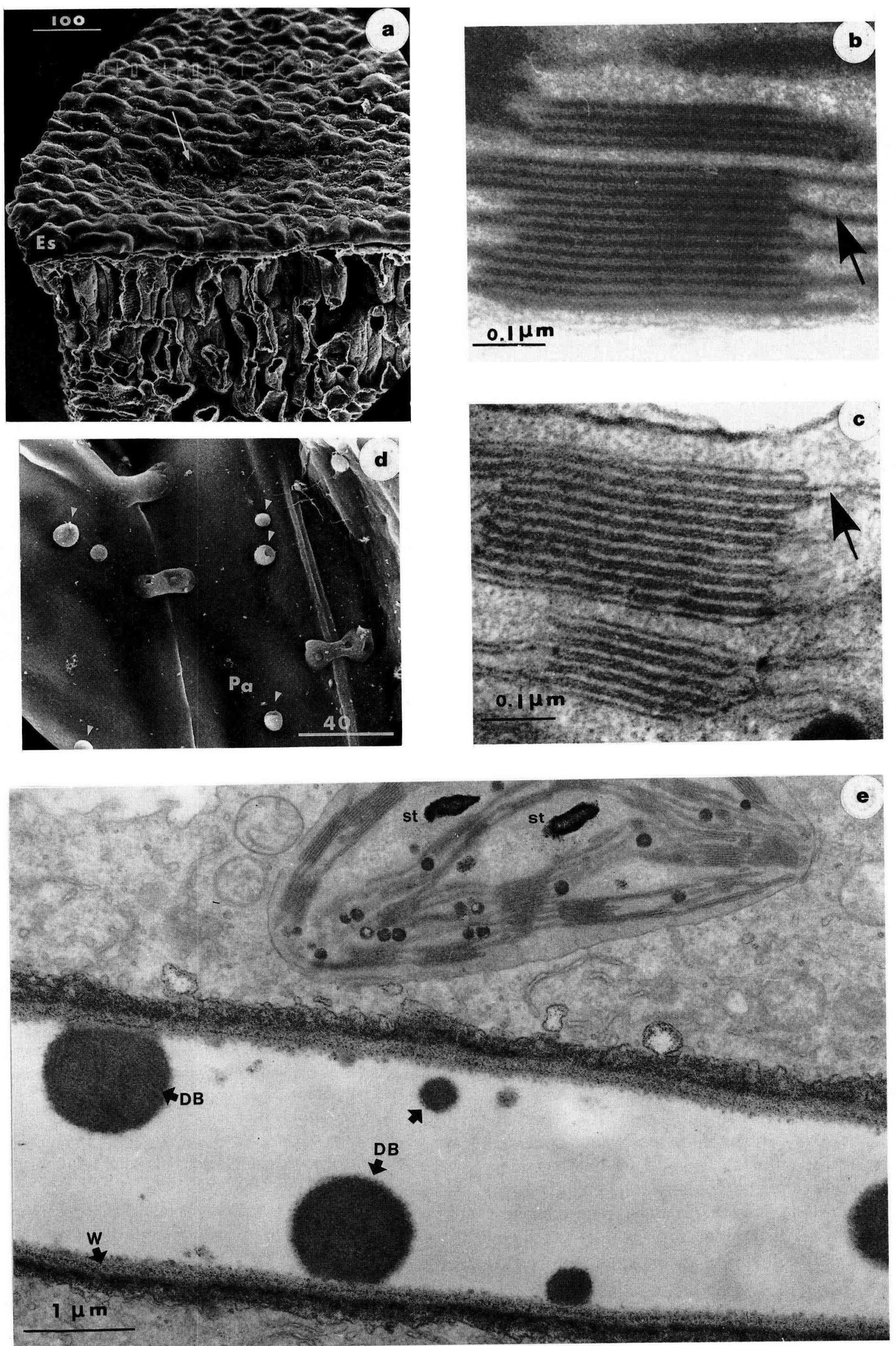
The accumulation of electron-dense bodies in the peripheral regions observed on line $29 \mathrm{H}$ has also been reported in $V$ faba by Abu-Zinada et al (1973) in cells on the periphery of necrotic lesions caused by infection with Botrytis fabae. Such electron-dense bodies could be pockets of phytoalexins. Studies carried out with $B$ fabaeinfected faba bean leaves have shown that the highest concentration of the phytoalexin wyerone acid was found at lesion edges (Mansfield, 1982; Bailey, 1983). Moreover, in the hypersensitive reaction observed only on line $29 \mathrm{H}$, a few epidermal cells died and the observed tannin accumulation is probably associated with the accumulation of host-produced phenolic coumpounds. Ultrastructural changes in chloroplasts associated with this lesion type are similar to those reported in Coleus, tomato, maize and apples after microbial infection (Marty, 1976; Chevalier, 1991). The increase in the size and number of plastoglobi found in flecking lesions has also been reported in plant species other than $V$ faba such as lettuce, iris and aspen (Delon and Mangenot, 1975; Mlodzianowski and Siwecki, 1975; Delon et al, 1977). Cooper (1981) stated that such ultrastructural changes were compatible with an acceleration of normal senescence. Such alterations are likely to have resulted from the stress of parasitism rather than the direct effects of the pathogen or pathogen-produced toxin (Coffey et al, 1972; Delon and Mangenot, 1975).

The development of the fungus in intercellular spaces and even in vascular bundles in conjunction with the widespread destruction of host tissue suggests that $A$ fabae is behaving necrotrophically. Like many necrotrophs, this pathogen is able to kill susceptible tissue in advance of its mycelium, possibly due to the production of toxins. Ascochitine is a toxic benzopyran identified and purified from culture filtrates of $A$ fabae by Oku and Nakanishi (1964). Recently Beed has verified the production of this toxin in liquid culture by isolates of $A$ fabae originating from France, Tunisia and England (personal communication). Diffusion of ascochitine into vascular bundles up to leaf apices could explain the common spreading form of the lesions. The well-defined border between healthy and infected cells in limited lesions may be explained by the ability of the resistant line $29 \mathrm{H}$ to prevent toxin production by this pathogen.

However, it could be argued that $A$ fabae may behave biotrophically for a short period during the preliminary stages of infection. Dodd (1971), showed that following penetration, hyphae grew into the protoplasm of epidermal cells. Our observations of the early stages of infection confirm the intracellular development of hyphae in epidermal cells. It is also noteworthy that although penetration of host epidermis was achieved within $48 \mathrm{~h}$, necrotic development only occurred after a further $6-8 \mathrm{~d}$. This period could represent a biotrophic stage necessary for subsequent necrotrophic growth. Similarly, the hypersensitive reaction characterised by the flecking lesions in the resistant line $29 \mathrm{H}$ is more commonly associated with a resistant response to infection by a biotrophic organism. Finally, $A$ fabae does not have the wide host range found in many necrotrophs.

\section{ACKNOWLEDGMENTS}

The authors wish to express their gratitude to $\mathrm{G}$ Boguais, L Communier (Université de Rennes I) for technical assistance and $M$ Le Lannic of the Centre de Microscopie à Balayage de I'Université de Rennes I. We are also indebted to $R$ Strange, $F$ Beed (University College London) and $\mathrm{G}$ Jellis (PBI Cambridge) for constructive discussions and improvement of the English version.

\section{REFERENCES}

Abu-Zinada AAH, Cobb A, Boulter D (1973) Fine structural studies on the infection of Vicia faba $L$ with Botrytis fabae Sard. Arch Mikrobiol 91, 55-66

Bailey JA (1983) Biological perspectives of hostpathogen interactions. In: The Dynamics of Host Defence (JA Bailey, BJ Deverall, eds) Academic press of Australia, Sydney, 1-33

van Breukelen EWH (1985) Screening faba beans for resistance to Ascochyta fabae by artificial inoculation of seedlings. Euphytica 34, 425-430

Chevalier M (1991) La résistance du pommier (Malus $x$ domestica Bork) à Venturia inaequalis (Cke) Wint: Étude histologique et ultrastructurale du symptôme de résistance en «piqûre d'épingle». CR Acad Sci, Ser III, 312, 117-124

Coffey MD, Palevitz BA, Allen PJ (1972) Ultrastructural changes in rust-infected tissues of flax and sunflower. Can J Bot 50, 1485-1492

Cooper RM (1981) Pathogen-induced changes in host ultrastructure. In: Plant Disease Control (RG Staples, GH Toenniessen, eds) Wiley \& Sons, New York, 105-142

Darby P, Lewis BG, Matthews P (1986) Diversity of virulence within Ascochyta pisi and resistance in the genus Pisum. Plant Pathol 35, 214-223 
Delon R, Mangenot F (1975) Étude ultrastructurale des interactions hôte-parasite. I-L'hétérosporiose de l'iris. Can J Bot 53, 1994-2005

Delon R, Kiffer E \& Mangenot F (1977) Ultrastructural study of host-parasite interactions. II-Delay of lettuce caused by Botrytis cinerea and phyllosphere bacteria. Can J Bot 55, 2463-2470

Dodd IJ (1971) Some aspects of the biology of Ascochyta fabae Speg (leaf and pot spot of the field bean, $V_{i-}$ cia faba L). PhD thesis, University of Hull, UK $162 \mathrm{pp}$

Jellis GJ, Lockwood G, Aubury RG (1984) Resistance to Ascochyta blight (Ascochyta fabae) in a winterhardy line of faba bean (Vicia faba equina). Fabis News/ 10, 27-29

Jellis GJ, Lockwood G, Aubury RG (1985) Phenotypic influences on the incidence of infection by Ascochyta fabae in spring varieties of faba beans (Vicia faba). Plant Pathol 34, 347-352

Lockwood G, Jellis GJ, Aubury RG (1985) Genotypic influences on the incidence of infection by Ascochyta fabae in winter-hardy faba beans (Vicia faba). Plant Pathol 34, 341-346

Mansfield JW (1982) The role of phytoalexins in disease resistance. In: Phytoalexins (JA Bailey, JW Mansfield, eds), Blackie, Glasgow, 253-288

Marty D (1976) Différenciation du système membranaire plastidial dans les feuilles panachées du Coleus blumei Benth, Thèse d'état, Université d'AixMarseille I/, France $162 \mathrm{pp}$

Maurin N (1989) Biologie d'Ascochyta fabae Speg et étude des relations hôte-parasite en vue de l'appréciation de la résistance de la féverole à l'anthracnose. Thèse doctorat, Univ Rennes I, France 132 pp
Maurin N, Tivoli B (1992) Variation among cultivars of Vicia faba infected by Ascochyta favae in relation with the disease evolution in field trials. Plant Pathol 41, 737-744

Mlodzianowski F, Siwecki R (1975) Ultrastructural changes in chloroplasts of Populus tremula L, leaves affected by the fungus Melampsora pinitorqua Braun Rostr. Physiol Plant Pathol 6, 1-3

O'Connell RJ, Bailey JA (1988) Differences in the extent of fungal development, host cell necrosis and symptom expression during race-cultivar interactions between Phaseolus vulgaris and Colletotrichum lindemuthianum. Plant Pathol 37, 351-362

Oku H, Nakanishi T (1964) A toxic metabolite from Ascochyta fabae having antibiotic activity. Phytopathology 53, 1321-1325

Ou SH (1980) Pathogen variability and host resistance in rice blast disease. Annu Rev Phytopathol 18, 167-187

Pritchard PR, Rowe PS, Rossall S (1989) A comparison of infection of resistant and susceptible lines of field beans (Vicia faba) by Ascochyta fabae. Plant Pathol 38, 266-270

Reynolds ES (1963) The use of lead citrate at high $\mathrm{pH}$ as an electron-opaque stain in electron microscropy. J Cell Biol 17, 208-212

Thiéry JP (1967) Mise en évidence des polysaccharides sur coupe fines en microscopie électronique. J Micros 6, 987-1017

Tivoli B, Reynaud B, Maurin N, Berthelem P, Le Guen $J$ (1987) Comparison of some methods for evaluation of reaction of different faba bean genotypes to Ascochyta fabae. Fabis News/ 17, 35-39 